\title{
Peripheral inflammation increases PKR activation, Tau phosphorylation and amyloid $\beta$ production in wild-type mice
}

François Mouton-Liger ${ }^{1,2^{*}}$, Anne-Sophie Rebillat ${ }^{1}$, Clarisse Pace ${ }^{1}$, Sarah Gourmaud ${ }^{1}$, Mariko Taga ${ }^{1,3}$, Claire Paquet ${ }^{1,2}$, Jacques Hugon ${ }^{1,2}$

From Molecular Neurodegeneration: Basic biology and disease pathways

Cannes, France. 10-12 September 2013

\section{Background}

Systemic inflammation is correlated with dementia progression. Pro-inflammatory molecules can communicate from the periphery to the central nervous system to induce neuroinflammation and neurodegeneration. Our protein of interest is the pro-apoptotic kinase PKR (the double strand-RNA dependent protein kinase). Increased activated PKR levels were found in AD patients brain and cerebrospinal fluid. PKR activation can be triggered by inflammatory stresses and induces neurotoxicity in vitro. Is in vivo PKR-mediated inflammation involved in $\mathrm{AD}$ neurodegenerative process?

\section{Learning objective}

To investigate whether PKR-mediated neuroinflammation could play a role in $\mathrm{AD}$ neurodegenerative process.

\section{Methods}

C57BL/6 wild type mice were injected intraperitoneally with LPS $(1 \mathrm{mk} / \mathrm{kg})$ versus saline once a day for 3 days to induce PKR activation and neuroinflammation (LPS is the bacilli gram negative endotoxin lipopolysaccharide).

Brains were collected and dissected; immunohistochemistry and western blotting were performed for neuroinflammation, PKR activation and AD pathological hallmarks (as Tau hyperphosphorylation).

\section{Results}

Mice showed endotoxin-induced sickness behaviour includingbody weight loss and elevated serum cytokine levels.

Inserm UMR-S839, Paris, France

Full list of author information is available at the end of the article
Microglial activation, neuronal apoptosis, increase of PKR, GSK3 $\beta$ and Tau phosphorylation and amyloid $\beta$ production were found in hippocampus and cortex of LPS-treated mice.

\section{Conclusions}

PKR could be involved in the signalling of neurofibrillary tangles formation after a systemic inflammatory challenge.

\section{Authors' details}

'Inserm UMR-S839, Paris, France. ${ }^{2}$ Hopital Lariboisière APHP, Paris, France.

${ }^{3}$ University of Southampton, Southampton, UK.

Published: 13 September 2013

\section{doi:10.1186/1750-1326-8-S1-P32}

Cite this article as: Mouton-Liger et al:: Peripheral inflammation increases PKR activation, Tau phosphorylation and amyloid $\beta$ production in wild-type mice. Molecular Neurodegeneration 2013 8(Suppl 1):P32.

Submit your next manuscript to BioMed Central and take full advantage of:

- Convenient online submission

- Thorough peer review

- No space constraints or color figure charges

- Immediate publication on acceptance

- Inclusion in PubMed, CAS, Scopus and Google Scholar

- Research which is freely available for redistribution

Submit your manuscript at www.biomedcentral.com/submit

\section{Ciomed Central}

๑ 2013 Mouton-Liger et al; licensee BioMed Central Ltd. This is an Open Access article distributed under the terms of the Creative Commons Attribution License (http://creativecommons.org/licenses/by/2.0), which permits unrestricted use, distribution, and reproduction in any medium, provided the original work is properly cited. 